\title{
負荷予測誤差が最適化結果に及ぼす影響とロバストな最適化手法の提案 空調システム運用の最適化ツールの開発（その 1$)$ \\ EFFECTS ON OPTIMIZATION RESULTS BY THERMAL LOAD PREDICTION ERRORS AND PROPOSAL OF ROBUST OPTIMIZATION METHOD
}

Development of optimization tool for air-conditioning system operation (Part 1)

\section{住吉大輔*, 和田晃史 ${ }^{* *}$, 赤司泰義***, 林 徹夫**** \\ Daisuke SUMIYOSHI, Akifumi WADA, Yasunori AKASHI and Tetsuo HAYASHI}

\begin{abstract}
The purpose of this research is to develop "The Optimization Tool" that achieves the optimization of the air-conditioning system operation in general building air-conditioning systems. The influence of errors in the load prediction, which is the biggest problem in realizing the optimization, is examined in this report. It is shown that there is a case where the operation deteriorates due to the optimization when the margin of error is large. Thus, an optimization technique that takes into account errors in the load forecasting is suggested, and the technique is proved to be a robust procedure which stably selects appropriate set values.
\end{abstract}

Keywords: Energy Conservation, Air-conditioning System, Optimization, Prediction Error, Simulation 省エネルギー、空調システム、最適化、予測誤差、シミュレーション

1. はじめに

\section{1 研究の背景}

空調システムの省エネルギーを実現するためには、「建物計画に よる空調負荷の削減」、「適切な空調システムの採用と設計」に加 えて、「空調システムの適切な運用」が不可欠である。しかしなが ら、これまでは「建物計画による空調負荷の削減」、「適切な空調 システムの採用と設計」に重点が置かれ、「空調システムの適切な 運用」に関しては室温湿度や機器の運転状況の確認といった初歩的 な日常業務に留まり、消極的な運用しかなされてこなかった。これ を解決する方法として空調システム運用の最適化が位置付けられる。 空調システムを長期にわたって使用していくと、設計時には想定 していなかった建物用途の変更や機器の増減による内部発熱の大幅 な変化、機器の劣化等が発生する。その際に、状況に応じた設定変 更が実施されることは稀であり、多くの場合、設定不全を抱えたま ま運転が継続されることとなる。空調システム運用の最適化は、通 常の空調システムにおいて固定的に扱われている設定值（例えば、 熱源機器の泠水出口温度、給気温度など）を日々変化する状況に応 じて最適な值にすることによって「空調システムの適切な運用」の 実現を目指寸ものである。

\section{2 空調システム運用の最適化実現に向けた課題}

空調システム運用の最適化については、古くから数多くの研究が なされてきた。にもかかわらず、いまだに最適化を実際の運用に導
入している空調システムはごく稀である。最適化の一般的なシステ ムへの普及における問題点について以下にまとめた。

(1)予測の不確実性に関する問題

空調システム運用の最適化の多くは気象・内部発熱予測、もしく は熱負荷予測に基づいて、空調システムシミュレーションをべース とした最適化計算を実施するものである。しかしながら、元来、予測 值を実現值に一致させることは不可能であり、さらに、省エネルギ 一の観点から最適化の導入効果が高いと予想される膨大な建築ス卜 ックへの適用と、既存ビルに特有の高精度な予測に必要な各種デー 夕取得の困難さを併せて考えれば、自ずとその予測精度には限界が あると思われる。こういった不可避な予測誤差は、最適化による省 エネルギー効果を著しく損なうことが危惧される。

しかしながら、これまでの最適化研究のほとんどが、計算に使用 する気象・内部発熱、もしくは熱負荷の予測は正確に行えることを 前提に開発されており例えば 1),2,3)、誤差を含む予測データを用いた際 に効果が得られるかは明らかにされていない。

(2)シミュレーションプログラムの経年変化への適応の問題

空調システムをシミュレートする際、機器の特性も誤差要因の一 つである。その誤差は機器の劣化によってさらに大きくなる恐れが ある。したがって長期間の運用においては機器の特性を補正する必 要がある。また、建物使途の変化は内部発熱や空調スケジュールの 大幅な変化につながる。特に、過去のデータを用いて熱負荷を予測 するような手法を採用した場合、こうした変化への対応策も長期に
* 独立行政法人建築研究所 研究員 · 博士 $($ 工学 $)$

** (株)大林組 修士 (工学)

$* *$ 九州大学大学院人間環境学研究院 准教授 ·博士 (工学)

**** 九州大学大学院総合理工学研究院 教授. 博士 (工学)
Researcher, Building Research Institute, Dr. Eng.

Obayashi Corporation, M. Eng.

Assoc. Prof., Faculity of Human-Environment Studies, Kyushu Univ., Dr. Eng.

Prof., Faculty of Engineering Sciences, Kyushu Univ., Dr. Eng. 
わたって空調システム運用の最適化を行う際には重要である。

(3)コストに関する問題

空調システム運用の最適化を導入する際のコストが不明である。 特に、これまでの空調設備に加えて新たに導入すべき機器が何で、 その導入費用がどの程度であるかは重要である。また、最適化に際 して多くのセンサーを設置することは、システムの運転状態を正確 に把握する上で重要であり、センサー数が多いほどより適した運転 を実現できると考えられる。しかしセンサーの導入にも費用がかか り、費用対効果を考えた最適化手法の開発が必要といえる。また、 センサー数が制限されれば負荷予測の精度にも影響を及ぼす。

(4)運用上の制約条件に関する問題

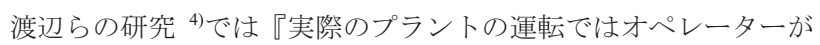
圧力、流量の確保や圧力変動の最小化のため、コストミニマムに反 する運転を行う可能性がある。』としている。こうした制約条件は、 最適化を実装する上で検討が難しく、条件次第では最適化効果に大 きな影響を与える。したがって、最適化を行う前に個々のシステム に応じた制約条件を定めておく必要がある。

\section{3 研究目的}

本研究の目的は、一般的なビル空調システムにおいて空調システ ム運用の最適化を実現する”最適化ツール”の開発を行うことである。 前節で述べたように、空調システム運用の最適化の普及に向けては いくつかの問題点がある。中でも、前節(1)に挙げた予測の不確実性 に関する問題では、実際の状況にそぐわない設定值を最適な設定值 として出力してしまうことにより、通常の運用に比べてエネルギー 消費量が増大したり、制御状態が悪化したりする恐れがあることか ら、対策が不可久な課題と言える。予測精度を向上させる従来のア プローチだけでは限界があり、予測が正確に行えないことを前提と して、誤差に対してロバストな効果が期待できる最適化手法の開発 が必要である。そこで本報では、設定值を日々変更する運用の最適 化を行った際の省エネルギー効果を把握し、予測誤差が最適化結果 に与える影響を明らかにする。また、運転状況を判断する評価関数 が最適化結果に与える影響について検討を行う。さらに、予測誤差 を考慮したより確度の高い最適化手法の提案とその効果の把握を行 う。なお、熱負荷予測は通常蓄熱式空調システムにおいて用いられ る手法であるが、本報では実験による基礎的な知見を得るため、蓄 熱槽を持たない実験施設を対象として検討を進めた。ここで提案す る手法は、対象が蓄熱空調システムであっても適用することができ るものである。なお「最適化手法」という用語は、狭義には『目的 関数を最適化するための数学的アルゴリズム』を意味するが、ここ では『最適化を実施する方法や手順』までを含めた広義な用語とし て使用している。また、実際には予測誤差に加え、最適化計算に用 いる空調システムシミュレーションの精度による誤差も存在するが、 本研究では空調システムシミュレーションは正確に実現象を再現で きるものと仮定している。

\section{2. 最適化の流れと対象建物の概要 \\ 2. 1 最適化の流れ}

本研究で開発するッールの概念図を図 1 に示す。ツールは気象・ 内部発熱予測部と最適化計算部とに分けられる。気象・内部発熱予
測部では、天気概況予報(晴れ・曇り等)、過去の運転データから気 象・内部発熱予測を行うことを想定する。それらを入力として、最 適化計算部では建物の空調システムシミュレーションを行い、最適 化計算により給気設定温度や熱源出口設定温度といった各種設定值 について最良と考えられる值を算出する。本ツールは空調システム の既存の設定值を書き換えるため、導入の際に空調システム内の複 雑な制御プログラムの変更を伴わない。そのため、BEMS と通信で きる計算用の $\mathrm{PC}$ と設定值を書き換えるプログラムを追加するだけ で導入することが可能であり、既存の空調システムにも容易に適用 できるものである。

\section{2 対象建物・空調システム概要}

九州大学筑紫キャンパスに位置する HVAC\&R 実験解析システム を対象とする。写真 1 に HVAC\&R 実験解析システムの外観を示す。 また、1 階平面図、断面図、空調システム図を図 2 、図 3、図 4 に、 建物概要、空調システム概要を表 1 、表 2 に示す。HVAC\&R 実験解 析システムは一般に広く導入されているエアハンドリングユニット を使用した中央供給方式を採用している。熱源機器は ON/OFF 運転 を行う。冷温水弁では、給気温度が設定温度になるようにPI 制御に よって開度が調整される。また、バイパス弁では、AHU 前配管内圧 力が設定圧力になるように PI 制御による配管内圧力制御が行われ る。各階の VAV ユニットは室温が設定温度となるようにダンパ開 度を制御し、風量を調節する。本システムは排気系統を持たない。 給気量に対して還気量が少なく、残りは室から排気されるシステム となっている。

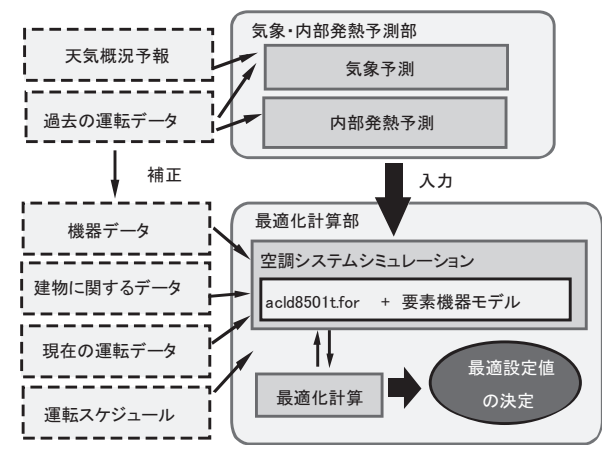

図 1 空調システム運用の最適化ツールの概念図

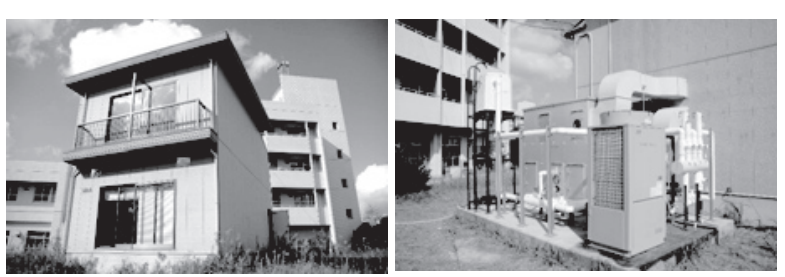

写真 1 HVAC\&R 実験解析システム外観

表 1 建物概要

\begin{tabular}{l|l}
\hline 所在地 & 福岡県春日市 (九州大学大学筑紫キャンパス) \\
\hline 用途 & 実験棟 \\
\hline 建築面積 & $35.84 \mathrm{~m}^{2}$ \\
\hline 延床面積 & $107.53 \mathrm{~m}^{2}$ \\
\hline 階数 & 地下 1 階、地上 2 階 \\
\hline 高さ & 軒高 $6.15 \mathrm{~m} 、 1$ 階階高 $2.70 \mathrm{~m}$ \\
\hline 構造 & 壁式鉄筋コンク リートハル造 (階段室は木造 $)$ \\
\hline 熱損失係数 & $2.315 \mathrm{~W} /\left(\mathrm{m}^{2} \cdot \mathrm{K}\right)$ \\
\hline 気密性 & 自然換気回数 $: 0.054$ 回 $/ \mathrm{h}(1$ 階測定值 $) ※$ \\
\hline
\end{tabular}
※相当隙間面積は未計測 


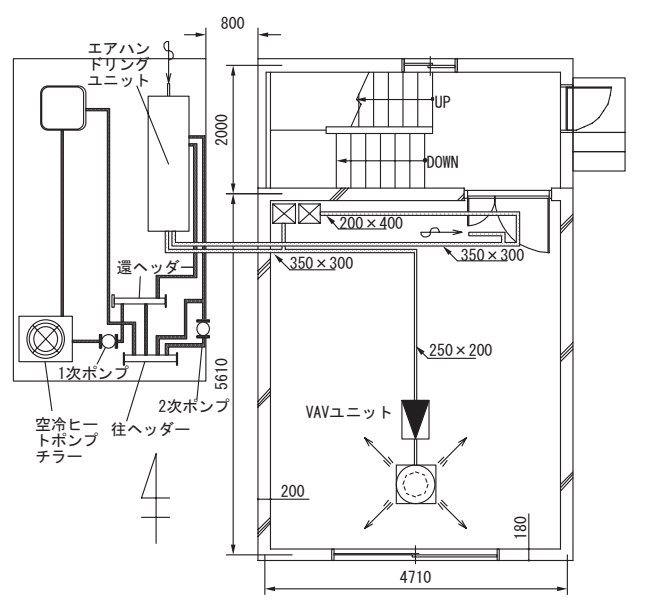

図 21 階平面図 (単位: $\mathrm{mm}$ )

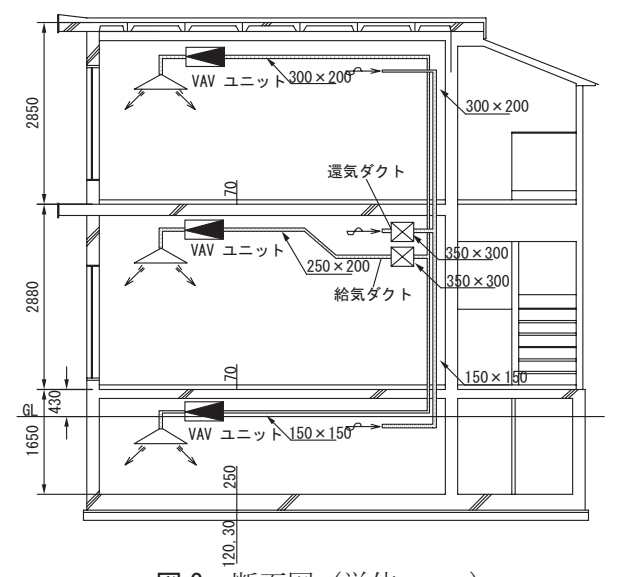

図 3 断面図 (単位: $\mathrm{mm}$ )

\section{3. 評価関数と予測誤差が最適化結果に及ぼす影響}

空調システム運用の最適化では運転状態を評価する関数(以下、評 価関数)を設定し、設定した関数により算出される評価值の最大化、 あるいは最小化を図るのが一般的である。通常、評価関数は最適化 したい項目(電力消費量、コスト等)および制約条件（室温、室内湿 度等）を取り込夕作成する。したがって、評価関数の設定次第で最 適化の結果も変わってくる。ここでは、室温と電力消費量の 2 つを 指標とした評価関数を設定し、両者のバランスによる最適化結果の 違い及び予測誤差が最適化結果に及ぼす影響についても検証する。

\section{1 シミュレーション概要と最適化計算の方法}

シミュレーションによる検討を行うため HVAC\&R 実験解析シス テムをモデルとしたシミュレーションプログラムを構築した。本プ ログラムは、建物の熱負荷計算に計算時間間隔を 1 分まで短くする ことができるように改造した HASP/ACLD/85015)を用い、 HASP $/ A C S S / 8502^{6}$ や HVACSIM $+{ }^{7}$ ) 参考に作成した要素機器モデル、 制御系モデル等と組み合わせて HVAC\&R 実験解析システムの挙動 を再現できるように全体を構築したものである。なお熱源機器モデ ルには、実機のカタログより能力特性式・入力特性式を作成し、外 気温度・熱源冷温水出口温度によって能力・入力が変化するモデル を用いている。また、外気量は常に $200 \mathrm{~m}^{3} / \mathrm{h}$ 導入されるものとし、 給気量に応じて還気量が変化することで風量バランスを保つ計算と している。

空調時間帯は 9 時〜 18 時、計算時間間隔は 5 分である。 1 月から

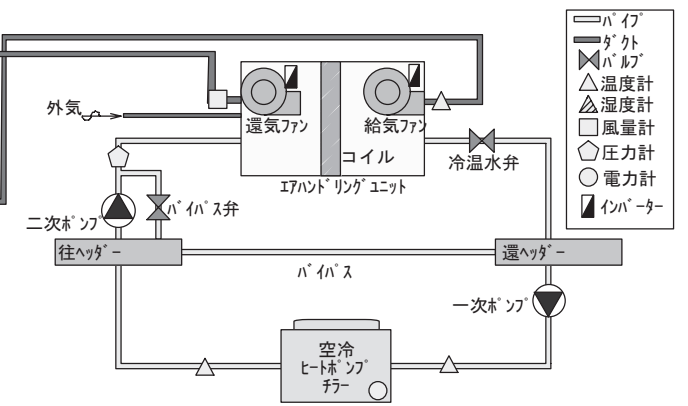

図 4 空調システム図

\begin{tabular}{|c|c|c|}
\hline 名称 & 機器仕様 & \\
\hline \multirow{3}{*}{$\begin{array}{l}\text { エアハンドリング } \\
\text { ユニット }\end{array}$} & 冷却能力 & $10.5 \mathrm{~kW}$ \\
\hline & 加熱能力 & $10.5 \mathrm{~kW}$ \\
\hline & 冷温水流量 & $1.86 \mathrm{~m}^{3} / \mathrm{h}$ \\
\hline \multirow{2}{*}{ 給気ファン } & 定格風量 & $2000 \mathrm{~m}^{3} / \mathrm{h}$ \\
\hline & 定格消費電力 & $1.5 \mathrm{~kW}$ \\
\hline \multirow{2}{*}{ 還気ファン } & 定格風量 & $1800 \mathrm{~m}^{3} / \mathrm{h}$ \\
\hline & 定格消費電力 & $1.5 \mathrm{~kW}$ \\
\hline \multirow{2}{*}{ 加湿器 } & \multicolumn{2}{|l|}{ 気化式 } \\
\hline & 有効気化量 & $2.0 \mathrm{~kg} / \mathrm{h}$ \\
\hline \multirow{4}{*}{$\begin{array}{l}\text { 空冷ヒートポンプ } \\
\text { チラー }\end{array}$} & 泠却能力 & $12.5 \mathrm{~kW}$ \\
\hline & 加熱能力 & $15 \mathrm{~kW}$ \\
\hline & $\begin{array}{l}\text { 定格消費電力： } \\
\text { 加熱時 } \\
\end{array}$ & $5.2 \mathrm{~kW}$ \\
\hline & \begin{tabular}{|l} 
定格消費電力： \\
冷却時
\end{tabular} & $5 \mathrm{~kW}$ \\
\hline \multirow[t]{3}{*}{ 一次ポンプ } & \multicolumn{2}{|l|}{ ライン型 } \\
\hline & 冷温水流量 & $2.7 \mathrm{~m}^{3} / \mathrm{h}$ \\
\hline & 定格消費電力 & $0.4 \mathrm{~kW}$ \\
\hline \multirow[t]{3}{*}{ 二次ポンプ } & \multicolumn{2}{|l|}{ ライン型 } \\
\hline & 泠温水流量 & $2.4 \mathrm{~m}^{3} / \mathrm{h}$ \\
\hline & 定格消費電力 & $0.4 \mathrm{~kW}$ \\
\hline
\end{tabular}

3 月、 12 月を冬期、 6 月から 9 月を夏期、残りの月を中間期とし、 冬期は暖房運転、夏期・中間期は冷房運転を行う。設定室温は冬期 $22^{\circ} \mathrm{C}$ 、夏期 $26^{\circ} \mathrm{C}$ 、中間期 $24^{\circ} \mathrm{C}$ である。土曜日、日曜日、祝日は空調 しない。最適化を実施する際は、空調開始 1 時間前の 8 時に当日の 給気設定温度と熱源冷温水出口設定温度を評価值に基づき決定する 計算(以下、最適化計算)を行うことを想定し、8 時までのデータを既 知として扱う。なお、気象条件や室の使用状況は 1 日の中でも大き く変化することが予想されるため、設定值の選択周期を短くするこ とが考えられるが、その周期によっては計算負荷が増大寸ること、 ハンチングなどの制御上の問題点が発生する可能性があることなど から、ここでは 1 日を通してそれぞれ 1 つの設定值を選択する方法 をとった。どの程度の周期で設定值を変更すべきかは、今後の検討 課題としたい。

図 5 に最適化計算の計算フローを示す。最適化計算では、給気設 定温度と熱源冷温水出口設定温度を選択肢に応じて変更しながら空 調システムシミュレーションを繰り返し実施し、各設定值における 評価值を算出する。そして、評価值が最小となる給気設定温度と熱 源冷温水出口設定温度の組み合わせを当日の設定值として選択寸る。 設定值の選択肢を表 3 にまとめる。給気設定温度の選択肢 8 点と熱 源冷温水出口設定温度の選択肢 11 点の組み合わせである 88 通りを 総当りですべて計算し、評価值が最小となる組み合わせを探索する。 
なお、図 5 中の仮想冷房負荷とは、室温湿度が 24 時間常に一定の 仮定值(基準温湿度)をとったときに室に入ってくる熱量を表す HASP/ACLD/8501 の出力データである。HASP/ACLD/8501 では、基 準温湿度から室温湿度がずれたときに生じる蓄熱負荷（室の空気か ら室を取り囲む壁などへ向かう熱流）と仮想冷房負荷との重ねあわ せで除去供給熱量と室温湿度の関係を捉えている。

本報では既存空調システムへも簡単に導入できるツールを目指す ため、最適化の方法として設定值を書き換える手法をとったが、夜 間換気や外気導入、予冷予熱運転などを導入することは効果が大き いと考えられる。これらも今後の検討課題としたい。

\section{2 評価関数が最適化結果に及ぼす影響}

\section{2.1 検討ケース}

空調システムの運転状態を評価する評価関数を式 1 、式 2 に示す。

$$
V=E_{a c}+\frac{W \times P_{R}}{100}
$$

ここで、 $V$ : 評価值 $[\mathrm{kWh}] 、 E_{a c}$ : 空調システムの日積算電力消費量 $[\mathrm{kWh}]$ $W:$ 室温によるペナルティの重み付け係数[\%]、 $P_{R}$ : 室温によるペナルティ $[\mathrm{kWh}]$

$$
P_{R}=\frac{C\left(D_{B}+D_{1}+D_{2}\right)}{3}
$$

ここで、C : 室温によるペナルティへの変換係数 $[\mathrm{kWh} /(\mathrm{K} \cdot \mathrm{h})](=$ 冬期 $: 520.9$ 、 夏期 : 2878.3、中間期 $: 1342.3) 、 D$ : 各階の室温と設定室温との偏差の絶対 値の積分値 $[\mathrm{K} \cdot \mathrm{h}]($ 添え字は階を表す)

式 2 の は、設定室温と実現された室温との差が $0.5 \mathrm{~K}$ 以上の場 合に付加するペナルティ值を算出するための変換係数であり、設定 室温を $1 \mathrm{~K}$ 変化させた場合の電力消費量の変化量をシミュレーショ ンにより計算し、それを基に冬期、夏期、中間期ごとに設定した。 これにより、実現室温と設定室温との差を $\mathrm{kWh}$ の次元に変換し、電 力消費量に付加しても意義のある数值とすることを意図している。 式1のWは室温によるペナルティと電力消費量の評価関数における バランスを決定するパラメータである。W が大きいほど室温の制御 状態を重視する評価関数となり、小さいほど電力消費量の低減を重 視する評価関数となる。そこで W の值を $0.1 \% 、 0.2 \% 、 0.5 \% 、 1 \%$ 、 $2 \% 、 5 \% 、 10 \% 、 20 \% 、 50 \% 、 100 \%$ と変化させながら、以下に示す 検討ケースについて計算することで最適化結果の違いを検討した。 ケース A : 対象システムで標準的に用いている設定值による運転を 再現するケース。設定值は表 3 中に下線で示している。図 6 に計算 フローを示す。仮想冷房負荷データには、1995 年の拡張アメダス気 象データ(福岡)を入力し改造した HASP/ACLD/8501 により算出した 仮想冷房負荷データ(以下、基準仮想冷房負荷データ)を用いる。

ケース B : 最適化計算を実施するケース。最適化計算により得られ た設定值を用いて空調システムシミュレーションを行う。図 7 に計 算フローを示す。仮想冷房負荷データには、ケース $\mathrm{A}$ と同様のもの を用いる。

なお、W の值を $0.1 \%$ としたケス $\mathrm{A}$ を $\mathrm{A}(0.1)$ 、ケース $\mathrm{B}$ を $\mathrm{B}(0.1)$ と表す。

\subsection{2 計算結果}

図 8 から図 11 にケース $\mathrm{A}$ 、ケース $\mathrm{B}(0.1)$ 、ケース $\mathrm{B}(1)$ 、ケース
$\mathrm{B}(100)$ について夏期代表日の計算結果を示す。ケース $\mathrm{B}(0.1)$ では室 温の制御状態によるペナルティを小さく評価したために、室温が制 御できない状態となっている。ケース $\mathrm{B}(1)$ とケース $\mathrm{B}(100)$ を比較す ると室温の制御状態にそれほど大きな違いは見られない。給気設定 温度も同レベルであるが、熱源冷水出口設定温度はケース $\mathrm{B}(100)$ の 方が低く、熱源の運転時間が増加している。通常、熱源冷水出口設 定温度が下がれば、必要流量の減少によりポンプの電力消費量が削 減されるが、対象空調システムでは二次ポンプにインバータ制御を 導入しておらず、バイパス弁による流量制御のため、ケース $\mathrm{B}(1)$ と ケース $\mathrm{B}(100)$ とでポンプの電力消費量はほとんど変わらない。

次に、各ケースの年間積算電力消費量の比較を図 12 に、室温によ るペナルティの年間積算值の比較を図 13 に示す。電力消費量と室温 によるペナルティはケース $\mathrm{A}(0.1)$ からケース $\mathrm{A}(100)$ まですべて同じ となるため、一つにまとめ $\mathrm{A}$ と表記した。図にはケース A を基準と した各ケースの比率を併せて記した。

室温によるペナルティの重み付け係数 W $0.1 \%$ として最適化を 行ったケース $\mathrm{B}(0.1)$ では、電力消費量がケース $\mathrm{A}$ に比べ $12.1 \%$ 削減 されたものの、室温の制御状態の悪化によりペナルティが $78.2 \%$ 増 加する結果となっている。特に夏期における室温の制御状態の悪化 が目立つ。室温によるペナルティの重み付け係数 $\mathrm{W}$ を $0.2 \%$ とした ケース $\mathrm{B}(0.2)$ でも、ケース $\mathrm{A}$ よりも $8.3 \%$ ペナルティが増加してい るがケース $\mathrm{B}(0.1)$ に比べかなりの改善が見られた。一方で電力消費 量はケース A に比べ $90.4 \%$ であり、ケース $\mathrm{B}(0.1)$ よりは増加した。 重み付け係数 W を増や寸ほど電力消費量が増加寸る結果となり、W が $20 \%$ 以上のケースではケース A よりも電力消費量が増加した。ま た、W が $20 \%$ 以上のケースでは室温の制御状態がほとんど変わらな い結果となった。

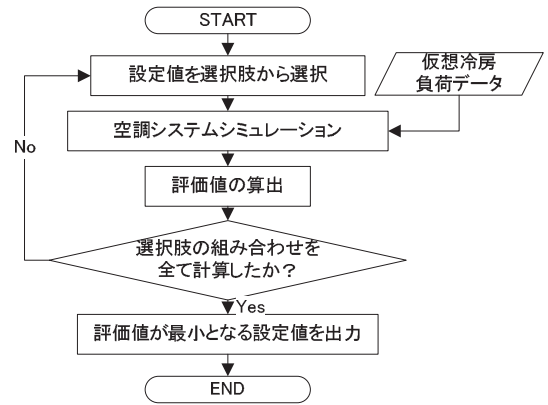

図 5 最適化計算の計算フロー 表 3 設定值の選択肢

\begin{tabular}{c|c|c}
\hline 設定值 & \multicolumn{2}{|c}{ 選択肢 } \\
\hline \multirow{2}{*}{ 給気設定温度 $\left[{ }^{\circ} \mathrm{C}\right]$} & 夏期 & $15 / 16 / 17 / 18 / 19 / 20 / 21 / 22$ \\
\cline { 2 - 3 } & 冬期 & $24 / 26 / 28 / \underline{30} / 32 / 34 / 36 / 38$ \\
\hline 熱源冷温水出口 & 夏期 & $5 / 6 / \underline{7} / 8 / 9 / 10 / 11 / 12 / 13 / 14 / 15$ \\
\cline { 2 - 3 } 設定温度 $\left[{ }^{\circ} \mathrm{C}\right]$ & 冬期 & $35 / 37 / 39 / 41 / 43 / 45 / 47 / 49 / 51 / 53 / 55$ \\
\hline
\end{tabular}
※下線は通常運転時の設定值

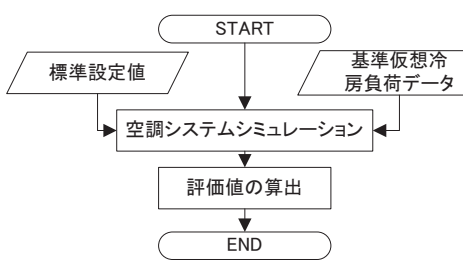

図 6

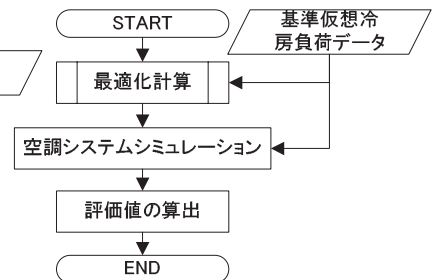

図 7 ケース $\mathrm{B}$ の計算フロー 


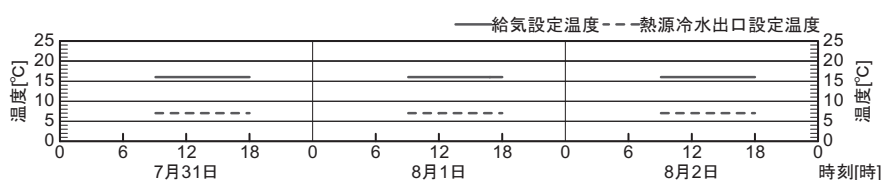

(a) 設定值

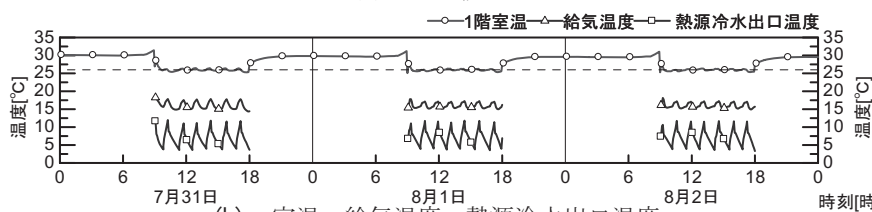

(b) 室温・給気温度・熱源冷水出口温度

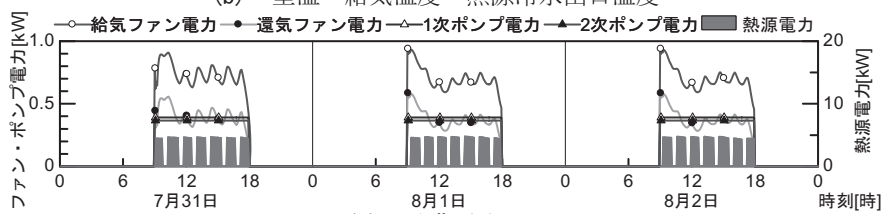

(c) 消費電力

図8 ケースA計算結果(夏期代表日)

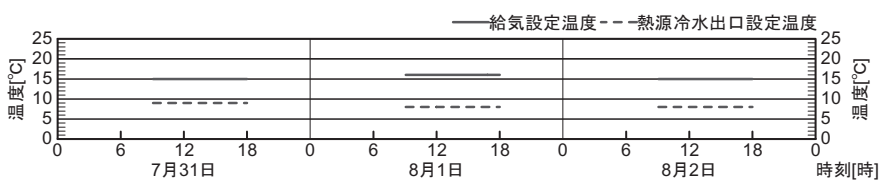

(a) 設定值

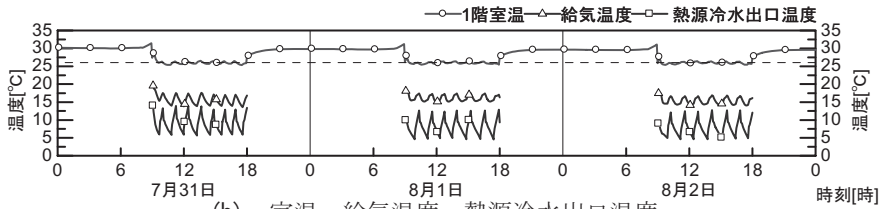

(b) 室温・給気温度・熱源冷水出口温度

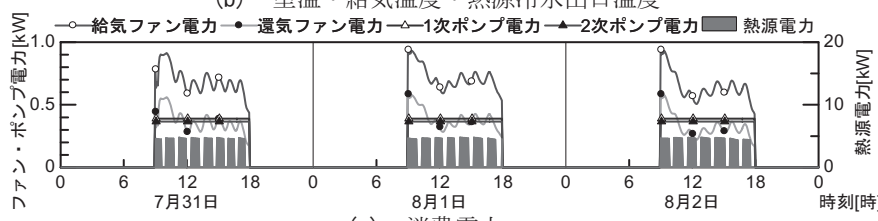

（c）消費電力

図10 ケースB(1)計算結果(夏期代表日)

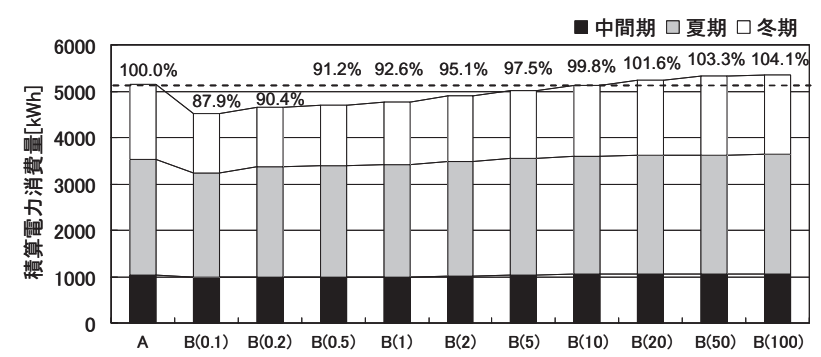

図 12 重夕付け係数 $\mathrm{W}$ による積算電力消費量の違い

評価関数は、対象とする空調システムの運用戦略に合わせて設定 する必要があり、たとえば室温の制御状態の改善を目指すのであれ ば重み付け係数 W を大きくすることになる。しかし、本検討結果が 示すように、室温制御に重みを置く評価関数としても室温の制御状 態はそれほど改善されず、電力消費量の増大を招く可能性もある。 評価関数の設定の際には運用戦略に応じてバランスの良い評価関数 を設定する必要がある。なお、本検討ではケース A に比べ室温の制 御状態、積算電力消費量とも改善が見られたのは W が $0.5 \%$ から 10\%までの範囲であった。

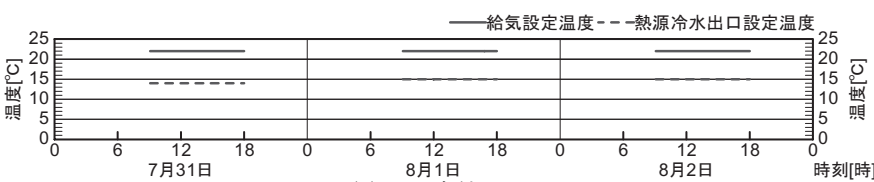

(a) 設定值

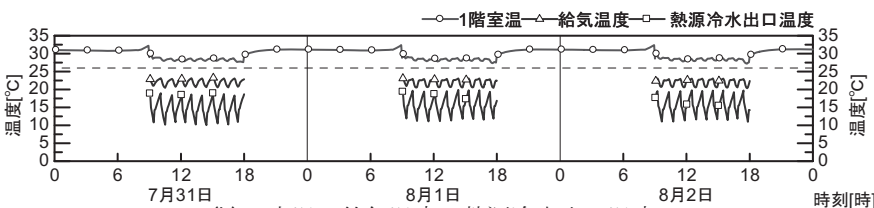

(b) 室温・給気温度・熱源冷水出口温度

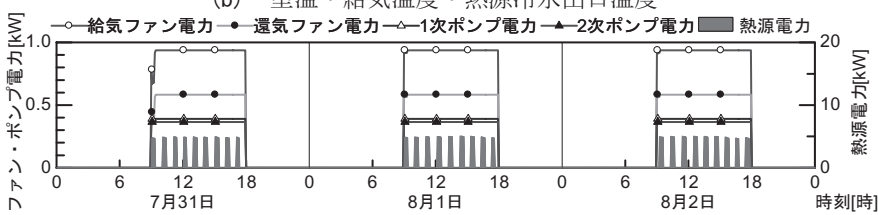

(c) 消費電力

図9 ケース B (0.1)計算結果(夏期代表日)

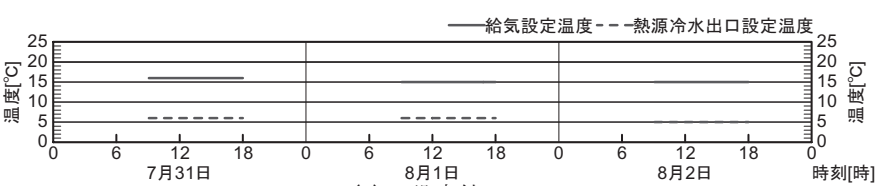

(a) 設定值

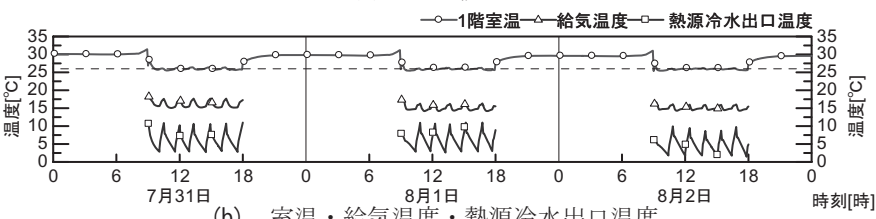

(b) 室温・ 給気温度・熱源冷水出口温度

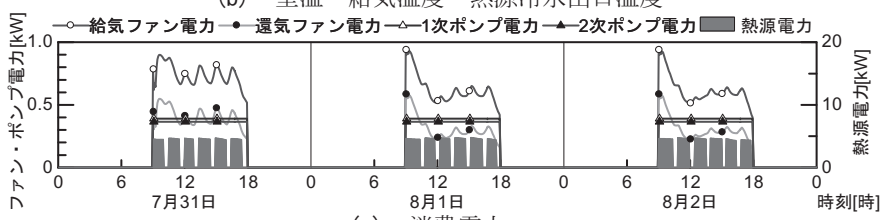

(c) 消費電力

図11 ケース B (100)計算結果(夏期代表日)

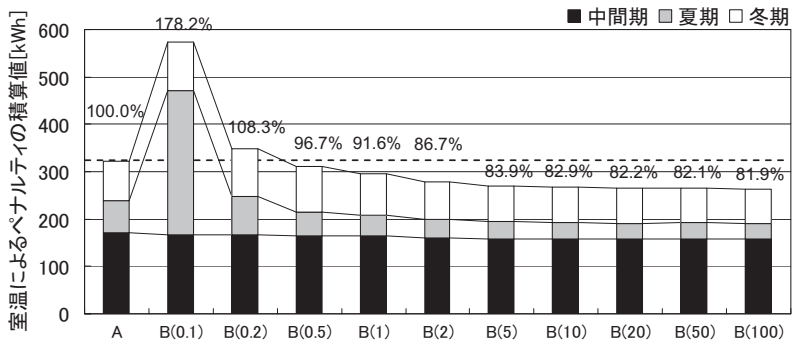

図 13 重夕付け係数 $\mathrm{W}$ によるペナルティ值の違い

\section{3 予測誤差が最適化結果に及ぼす影響}

\section{3.1 検討ケース}

予測誤差が最適化結果に及ぼす影響を明らかにするため、以下に 示寸ケース A からケース Cまでの 3 ケースのシミュレーションを実 施した。ここでは評価関数の重み付け係数 $\mathrm{W}$ を $1 \%$ に固定して分析 している。

ケース A: 通常運転を再現するケース(図 6)。3.2 節での検討と同様。 ケース B : 3.2 節での検討と同様の最適化計算を実施するケース(図

7)。予測誤差が全くない状況を再現したケースである。 
ケース C : 負荷の予測值に誤差が含まれる場合の最適化効果を試算 するケース。図 14 に計算フローを示す。実システムを再現する計算 にはケース B と同様に基準仮想冷房負荷データを用いるが、最適化 計算には基準仮想冷房負荷データの顕熱の值に $\mathrm{E} \mathrm{kW}$ を加えたデー 夕（以下、予測仮想冷房負荷データ）を用いる。 $\mathrm{E} \mathrm{kW}$ が予測に含 まれる誤差となる。図 15 に基準仮想冷房負荷データと予測仮想冷房 負荷データの関係を示す。検討では、3.26kW (2800kcal/h)を $100 \%$ と して、「+100」\%から「-100」\%までを 14 段階に分割した 14 ケー スの誤差 Eに関して計算を行う。誤差が「+100」\%のケースを $\mathrm{C}+100 、$ 「-100」\%のケースを C-100 と表す。なお、通常の 2 倍の機器発熱・ 人体発熱を想定した場合の試算結果では、仮想冷房負荷は平均 $0.955 \mathrm{~kW}(821 \mathrm{kcal} / \mathrm{h})$ 増加する。そのため、ここで設定した $100 \%$ $3.26 \mathrm{~kW}$ は実際に発生すると予想される誤差に対して十分に大きな 数值である。

\section{3. 2 計算結果}

図 16 に各ケースの電力消費量の比較を示す。図では予測誤差がな いケース B を中央に配置し、端に行くほど予測誤差が大きいケース となっている。予測誤差がマイナス側に大きくなるほど、つまり実 際よりも仮想冷房負荷を小さく予測したケースほど電力消費量が増 加する傾向がある。特に夏期の電力消費量の増加が目立つ。ケース C-57 より誤差が大きいケースでは積算電力消費量がケース A より も増加している。その一方で、予測誤差がプラス側に大きくなった 場合には電力消費量の変化はあまり見られない。ケース C-100 では、 ケース B に比べ $10 \%$ 積算電力消費量が増加した。

図 17 に各ケースの室温によるペナルティの比較を示す。予測誤差 が大きくなるにつれてペナルティも増加している。特にマイナス側 に誤差が大きい場合に、ペナルティの増加が目立ち、期間別では夏 期の増加が著しい。マイナス側はケース C-57、プラス側はケース $\mathrm{C}+29$ よりも予測誤差が大きい場合にケース A よりも室温の制御状 態が悪化している。室温によるペナルティはケース B よりもケース C-100 で 50\%、ケース C+100 で 20\%増加した。

図 18 にケース C-100、ケース B、ケース C+100 の夏期代表日につ いて選択された設定值を示す。最適な設定值であるケース B に比心゙、 負荷が実際よりも小さいものとして設定值を決めたケース C-100で は、給気設定温度が高く設定されている。そのため、風量を最大と しても負荷を処理できず、室温の制御状態が悪化した。また、ファ ンの動力も増え、電力消費量の増加にもつながっている。一方、ケ 一ス $\mathrm{C}+100$ では給気設定温度が低く設定されているため、風量を最 小としても室温が下がりすぎ、室の制御状態は悪化したが、ファン の動力は減少し、システム全体では電力消費量の増加が見られなか った。

図 19 に各ケースの評価值の比較を示す。予測誤差がマイナス側の ケースでは、ケース C-57 より誤差が大きい場合にケース A よりも 評価值が悪化した。ケース C-100 では、ケース A より $15 \%$ 評価值が 悪化している。一方で予測誤差がプラス側のケースには評価值がケ ース A よりも悪化するケースは見られなかった。こうした傾向は建 物の形状や空調システムの構成、選択可能な設定温度の範囲等の 様々な要因に影響されると考えられるが、夏期の最大負荷によりシ ステムの要素機器を選定している空調システムにおいて夏期に負荷

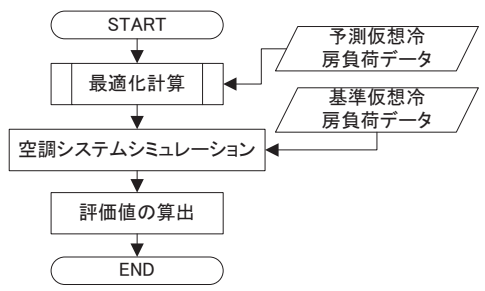

図 14 ケース $\mathrm{C}$ の計算フロー

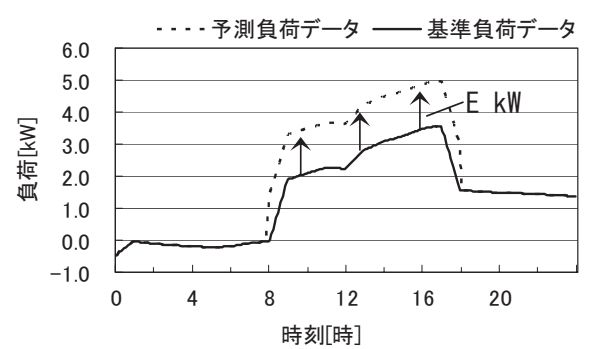

図15 基準仮想冷房負荷データと予測仮想冷房負荷データの関係

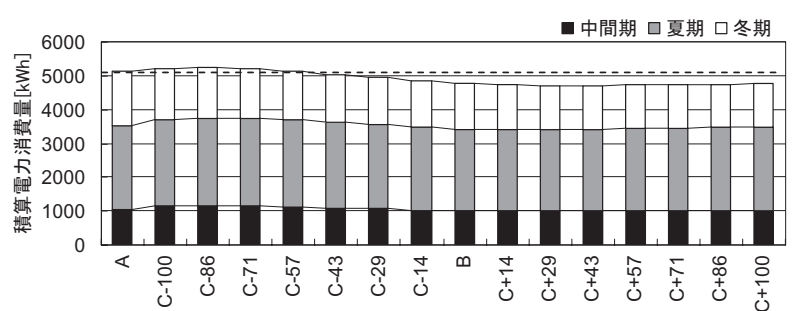

図16 予測誤差による積算電力消費量の違い
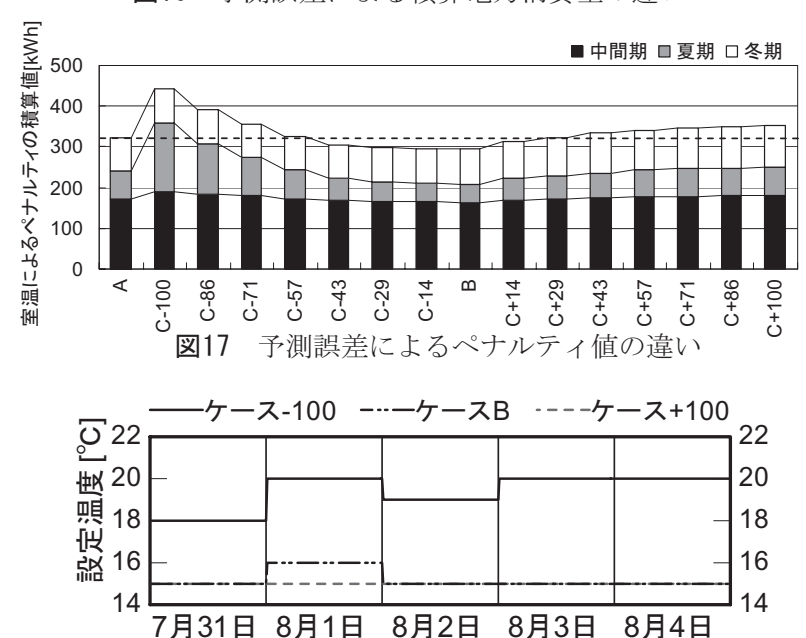

(a) 給気設定温度

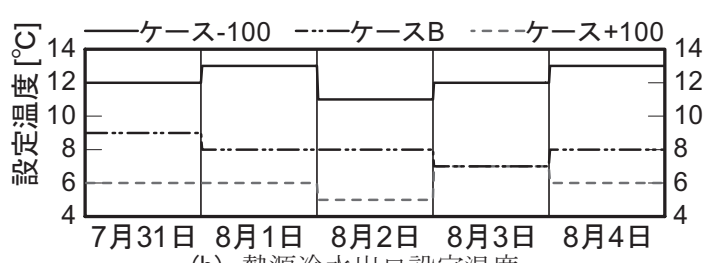

(b) 熱源冷水出口設定温度

図18選択された設定温度

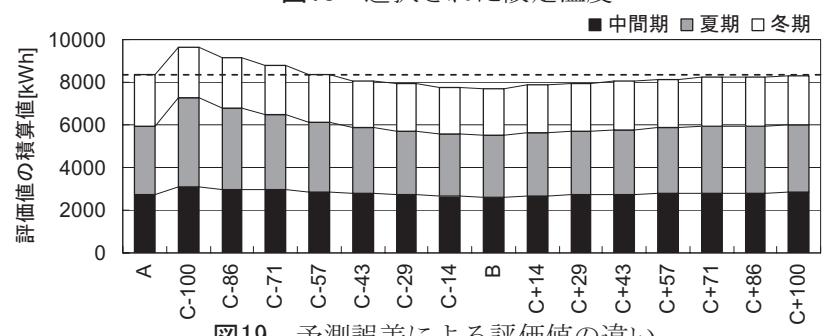

図19 予測誤差による評価值の違い 
を実際よりも小さく予測することは、処理能力不足を招きやすく、 室温の制御状態の悪化を引き起こしやすいため、危険である。

\section{4. 予測誤差を考慮した最適化手法とその効果}

前節での検討により、予測誤差が大きくなるにつれて最適化効果 が低下していくことが確かめられ、標準の設定值で運用した場合よ りも評価值が悪化するケースも見られた。こうした状況を防ぐには、 負荷予測に誤差が含まれていることを前提とした最適化手法の開発 が必要不可欠である。そこで本章では、予測誤差を考慮した最適化 手法を提案し、その効果の把握を行う。

\section{1 予測誤差を考慮したロバストな最適化手法}

図 20 に負荷と評価值の関係に関する概念図を示す。評価值は、給 気設定温度、熱源冷水出口設定温度等の設定值の組み合わせに対し て定まる。多くの最適化研究では負荷予測の誤差はないものと仮定 しているため、図中央の予測值に対して最適な設定值の組み合わせ を選択する。図の例では、設定值の組み合わせ $\mathrm{B}($ 以下、組み合わせ B)とした場合に設定值の組み合わせ $\mathrm{A}($ 以下、組み合わせ A) とした 場合よりも評価值がわずかに小さいため、組み合わせ B が選択され る。しかし実際の負荷が予測值 $+X \mathrm{kWh}$ であった場合には、組み合 わせ $\mathrm{A}$ とした方が有利であり、組み合わせ B では大きく評価值が悪 化する。誤差を考慮すれば組み合わせ A の方が安定性が高い設定值 であると判断できる可能性がある。

そこで、こうした状況を考慮して設定值を選択寸る最適化手法を 提案する。図 21 に従来の最適化手法の流れと誤差を考慮した最適化 手法の流れを示寸。従来の最適化手法(図 21(a))では予測負荷 L[kWh] に対して各設定值の組み合わせを評価し、評価の高いものを最適設 定值として選択寸ることをべースとしている。一方、提案する手法 (図 21(b))では、予測負荷 $L[k W h] に$ 対してだけでなく、L+X[kWh]や $\mathrm{L}-\mathrm{X}[\mathrm{kWh}]$ 等の負荷に対しても評価值計算を行う。誤差を表す $\mathrm{X}[\mathrm{kWh}]$ は過去の予測誤差の状況に応じて設定する。各負荷に対する 評価值を誤差 $\mathrm{X}[\mathrm{kWh}]$ の出現頻度 $\alpha$ に応じて重み付け平均すること により、各設定值の組み合わせの評価值とする。これにより負荷予 測の誤差に対してロバストな設定值の組み合わせを選択することが できると考えられる。なお、規模が大きな空調システムでは設定值 の組み合わせは莫大な数になる。3 章で用いた総当たり法では、こ うした莫大な数の組み合わせを全て計算することになるため計算負 荷が大きすぎる。そのため、設定值の組み合わせが多い場合には遺 伝的アルゴリズム ${ }^{8)}$ 等の最適化手法を用いることを想定している。

\section{2 予測誤差を考慮した最適化手法の適用効果}

提案する方法は数点の負荷予測值に対して平均的に評価值がよい 設定值の組み合わせを選択寸るため、突発的に大きく外れた予測值 が発生した場合でも、その周辺の負荷に対して平均的によい設定值 の組み合わせを選択する。したがって、突発的に大きく外れる予測 值による悪影響を緩和寸る効果があると考えられる。3 章で検討し たケース A、ケース C に加え、提案した方法を適用寸るケース D を 計算する。ケース D の計算フローはケース C と同様(図 14)であり、 最適化計算には誤差を考慮した最適化手法(図 21(b))を適用する。ケ ース C、ケース D の最適化計算に用いる予測負荷データには、誤差

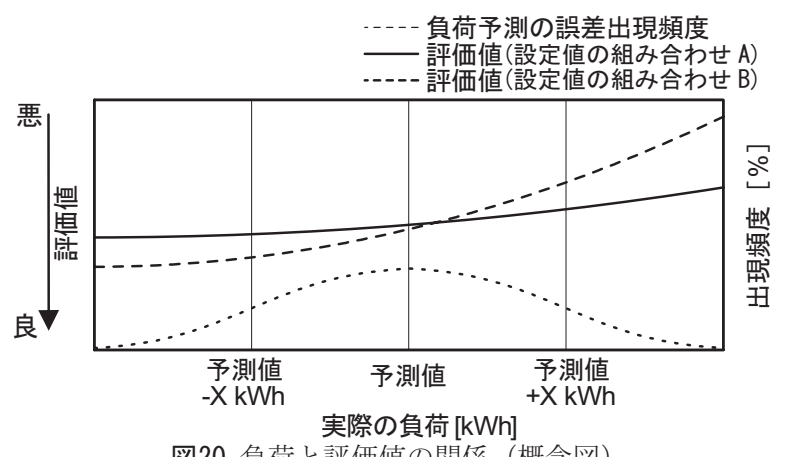

図20 負荷と評価値の関係（概念図）

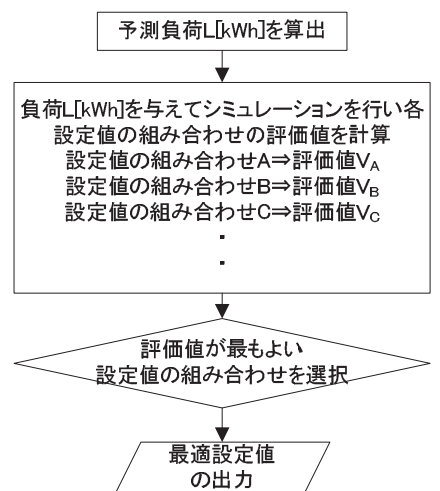

(a) 従来の最適化

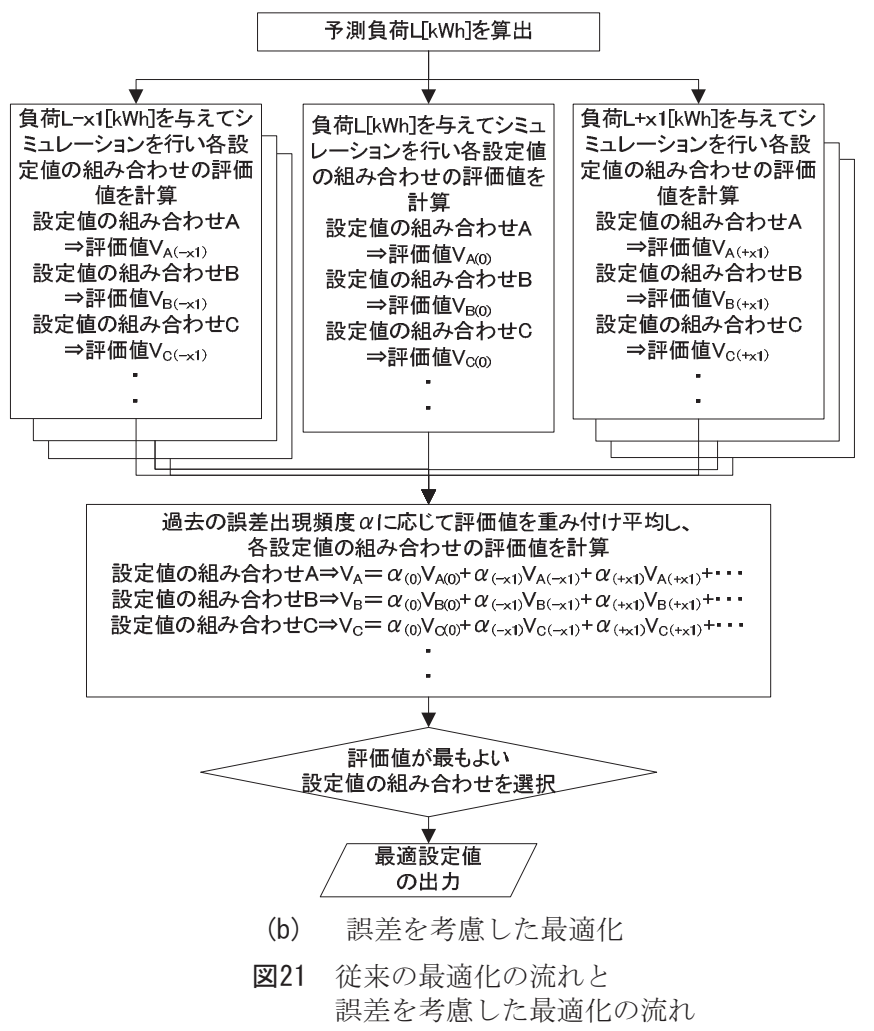

が 1 日ごとにランダムに出現するデータを用いた。ただし、誤差は 標準正規分布する乱数に $0.233 \mathrm{~kW}(200 \mathrm{kcal} / \mathrm{h})$ を乗じて与え、 $0 \mathrm{~kW}$ を 中心として $1 \mathrm{~kW}$ の範囲にほぼ収まっている。実際に負荷予測を行 った際にどの程度の誤差が現れるか不明であるため、ここでは通常 の機器発熱・人体発熱の 2 倍程度が出現する可能性のある誤差の範 囲と仮定し、事前の検討に基づきこのような設定とした。 
計算結果を図 22 に示す。図にはケース A に対する各ケースの比 率を併せて記載している。予測が完全に的中した場合を再現したケ ース B では、ケース A に対して評価值が 10.4\%改善しているが、予 測誤差を含むデータで最適化を行ったケース C では $8.4 \%$ にとどま っている。それに対して提案した手法を用いたケース D では、 $9.2 \%$ まで評価值の改善率が上がっており理想的なケースであるケース $\mathrm{B}$ に近づいていることが確認できる。

次に、提案した手法によってロバストな最適化が実現できている か確認するため 1 日ごとに計算結果を分析する。分析は、ケース A の評価值から各ケースの評価值を引くことで、各日における評価值 の改善量算出し、それを統計処理した。表 4 に各ケースの評価値の 改善量について平均、分散、最大值、最小值、マイナスとなる日数 を示す。ケース C に比ベケース D では平均值が高く、標準偏差が小 さい。このことからケース D では評価值の改善量が大きいところで まとまっていることが分かる。また評価值の改善量がマイナスとな る日数を比較するとケース C の 18 日に対し、ケース $\mathrm{D}$ では 8 日と 大きく減少している。これらのことから提案する最適化手法は、平 均的に高い効果が得られ、予測誤差の影響による運転状態の悪化を 抑えることができるロバストな手法であることが確認できた。

\section{5. おわりに}

本報では空調システム運用の最適化を実システムに導入する上て の課題をまとめ、負荷予測等に含まれる誤差が最大の課題であるこ とを述べた。

次に、評価関数が最適化結果に及ぼす影響と負荷予測の誤差が最 適化結果に及ぼす影響をシミュレーションにより定量的に把握した。 評価関数が最適化結果に及ぼす影響の検討では、評価関数を構成す る電力消費量と室温によるペナルティ值のバランスを規定する重み 付け係数 W には適切な範囲があることを明らかにした。負荷予測の 誤差が最適化結果に及ぼす影響の検討では、予測誤差が大きくなれ ば、設定值を変更しないで運転した場合よりも評価值が逆に低下し てしまうケースが見られた。特に、夏期に負荷を実際より小さく予 測した場合に最適化の効果が大きく損なわれる傾向にあり、誤差を 含む予測值を用いて最適化を行っても期待した効果が得られない可 能性があることが確かめられた。

そこで負荷予測の誤差を考慮した最適化手法を提案し、その効果 について検討した。その結果、予測誤差を考慮しない場合に比べ、 適切な設定值が安定的に選択されるロバストな手法であることを示 した。

次報以降では実際の負荷予測手法と組み合わせ、提案した最適化 方法の効果を実測調查・シミュレーションにより検討した結果につ いて報告する予定である。

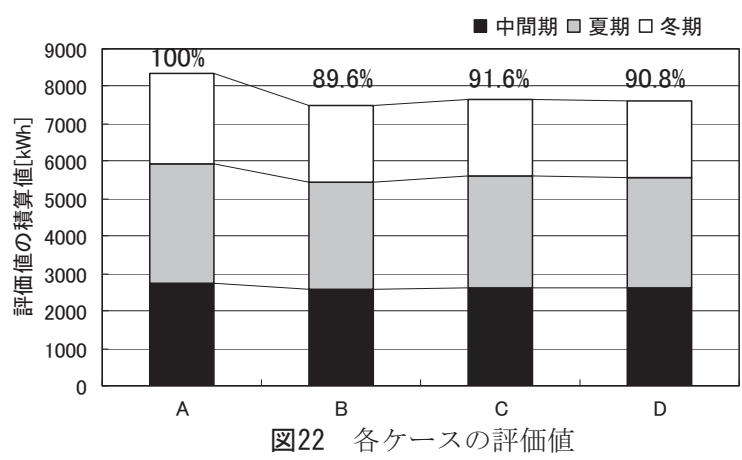

表4 各ケースの評価値改善量の統計值

\begin{tabular}{l|r|r|r}
\hline & ケース B & ケース C & ケース D \\
\hline 平均 $[\mathrm{kWh}]$ & 3.91 & 3.15 & 3.45 \\
\hline 標準偏差[kWh] & 2.31 & 2.59 & 2.42 \\
\hline 最大 $[\mathrm{kWh}]$ & 14.61 & 14.23 & 14.23 \\
\hline 最小 $[\mathrm{kWh}]$ & 0.00 & -1.96 & -1.42 \\
\hline マイナスとなる日数[日] & 0 & 18 & 8 \\
\hline
\end{tabular}

\section{参考文献}

1)松岡一平, 吉田治典, 井口悠也, 濱田和康 : 空調熱源と搬送システムの総 合最適運転法に関する研究, 空気調和·衛生工学会平成 14 年度学術講演会 講演論文集, pp.413-416, 2002.8

2)後藤祥仁, 吉田治典, 山口弘雅 : 蓄熱空調システムの最適運転法, 空気調 和·衛生工学会平成 11 年度学術講演会講演論文集, pp.989-992, 1999.8

3)長井達夫：躯体の熱容量を利用した動的最適化空調運転がエネルギー消費 特性に及ぼす影響について, 日本建築学会計画系論文集第 540 号, pp.45-52, 2001.2

4)渡辺健一郎, 太田勝, 神野正樹, 鎌田一宏, 大竹育男 : 熱源設備の運転支 援エキスパートシステムの開発 (その 3 ), 空気調和・衛生工学会平成 5 年度 学術講演会論文集, pp.333-336, 1993.10 5)松尾陽：HASP/ACLD/8501 解説，（社）建築設備技術者協会，1986.2 6)松尾陽，他：HASP/ACSS/8502 プログラム解説書，（社）建築設備技術者協 会, 1992.1

7)空気調和・衛生工学会コミッショニング委員会 WG : HVACSIM $+(J)$ 利用者 マニュアル, 1998.4

8)（社）電気学会 GA 等組合わせ最適化手法応用調查専門委員会 (C 部門) : 遺伝アルゴリズムとニューラルネット，コロナ社，1998.2.

（2008年11月27日原稿受理，2009年 3 月31日採用決定） 